\title{
Author Preprint:
}

Hegarty, P. (2002). "It's not a choice, it's the way we're built:" Symbolic beliefs about sexual orientation in the United States and in Britain. Journal of Community and Applied Social Psychology, 12, 153-166.

\begin{abstract}
Straight-identified Americans who believe that sexual orientation is immutable typically express more tolerant attitudes toward lesbians and gay men. Attribution theorists argue that this is because immutability beliefs reduce stigmatization. In two studies, 97 self-identified straight-identified American and 72 British students reported their beliefs about the immutability and fundamentality of sexual orientation, their attitudes toward lesbians and gay men, and their judgments about the values that those beliefs expressed. In both samples, tolerant attitudes and immutability beliefs were correlated only among participants who consistently judged that immutability beliefs would be expressed by more tolerant heterosexual persons. More condemning participants judged gay and straight people to be more fundamentally different in both samples. I argue that links between immutability and tolerance depend more on social constructions of immutability beliefs as expressive of tolerance and less on the attributional content of such beliefs than previous theorists have acknowledged.
\end{abstract}

\section{Author Note:}

Warmest thanks to Adrian Coyle and Xenia Chryssochoou who gathered the data for Study 2, to Kelly White who provided valuable assistance with Study 1, and to Adrian Coyle, Katie Cumiskey, Felicia Pratto and the anonymous reviewers who read earlier drafts of this manuscript. The author can now be contacted at Yale University, Larry Kramer Initiative for Lesbian and Gay Studies, 100 Wall Street, WLH 311, P.O. Box, 208334, New Haven, CT 06520-8334, USA.

\section{The Politics of Arguing from Immutability}

American readers may perceive the title of this article to be a contemporary gay rights slogan. In actuality it is a somewhat different public relations exercise. During the Summer of 2000 this legend accompanied an advertisement in the Castro neighborhood of San Francisco for the new Subaru 'all wheel drive system.' Subaru marketers are astute; studies show that most American lesbians and gay men consider their sexualities to be inborn rather than chosen (http://psychology/ucdavis.edu/rainbow/html/sacramento_study.html, 2001). As I discuss below, gay-affirmative straight Americans who saw the Subaru advertisement were also likely to recognize a vehicle for their politics in the billboard's deliberate double meaning.

Arguments that sexual orientations cannot be chosen are popular among liberal Americans of diverse sexualities. Such "arguments from immutability" (Halley, 1994) typically presume some deep-rooted biological entity which defines individuals as either gay or straight and which persists across the lifespan. Several biological studies have now claimed to have found signs of such essences in genes (Hamer, Hu, Magnusson, Hu, \& Pattatucci, 1993) brains (LeVay, 1991) genitals (Bogaert \& Hershberger, 1999), ears (McFadden \& Pasanen, 1998), and fingers (Williams et al., 2000). Such studies have been critically evaluated by biologists (Byne \& Parsons, 1993; FaustoSterling, 2000; Hamer \& Copeland, 1995; LeVay, 1996), historians (Terry, 1999), philosophers (Stein, 1992, 1999) and legal scholars (Halley, 1994). 
Arguments from immutability have several limitations as pro-gay strategies. First, biological essentialism is almost always complicit with heteronormativity. Reports of differences between gay and straight people prompt explanations that focus on attributes of gay people more than straight people and consequently these explanations can reiterate stereotypes (Hegarty \& Pratto, 2001). More generally, ostensibly pro-gay biological essentialism continue to frame gay and lesbian development as an excess, deficiency or imbalance relative to an implicit norm of heterosexual development (Sedgwick, 1993). Correspondingly, biological discourse rarely examines, defends, or promotes the possibility of mutating straight orientations into gay or lesbian ones. Rather, the discourse of mutability is framed exclusively and assymetrically in terms of the viability or desirability of turning gay people straight.

Second, arguments from immutability refer to biology to support claims that sexual orientations cannot be chosen. However the opposition of biology and choice may be particularly shortsighted in the contemporary moment. As Sedgwick notes;

[T] he gestalt of assumptions that undergird nature/nurture debates may be in a process of direct reversal. Increasingly it is the conjecture that a particular trait is genetically or biologically based, not that it is "only cultural," that seems to trigger an estrus of manipulative fantasy in the technological institutions of the culture (Sedgwick, 1993; pp. 78-79).

And manipulative fantasies did indeed unfold in response to recent biological essentialist research (see Stein, 1999). Journalist Chandler Burr predicted that tests for a "gay gene" would be performed on fetuses in the future, while geneticist Dean Hamer predicted that they would not (Gideonse, 1997). Neuroanatomist Simon LeVay (1996; p. 271) enthused about introducing 'a new eugenics' that will allow 'the genetically underprivileged . . . to decide whether they are indeed underprivileged or not, and if so to make the necessary adjustments in their offspring.' When 'choice' is understood to include decisions about child's future sexual practices, biological determinism appears not as the opposite of 'choice,' but rather as a source of technological fantasies about how future generations' sexual natures might be chosen.

Finally, biological determinist arguments represent the politics and experience of some gay men, lesbians, and bisexuals more than others. Terry (1997; p. 288) has argued that biological determinism appeals most to 'economically comfortable white men' in gay communities who have most to gain and least to lose by allowing science and existing social structures to define the discourse about sexuality. Biological essentialist politics remain androcentric; biological accounts have often neglected women's sexual subjectivity (e.g., Golden, 1993; Hegarty, 1997; Peplau et al., 1998; Terry, 1997). Most biological determinist studies focus on males (see McFadden \& Pasanen, 1998; Williams et al., 2000 for exceptions) and arguments from immutability do little to support bisexual and queer identities which refuse to abnegate choice or to remain within the categories of 'gay' and 'straight' (see e.g., Garber, 1995; Duggan, 1995). ${ }^{1}$ Thus, universalizing moves as biological essentialism often have the effect of creating division among the sexual minorities that they seek to unite (Butler, 1990; Phelan, 2001).

\section{Social Psychological Theories of Beliefs in Immutability}

Social psychological interest in arguments from immutability has focused less on these issues than on the attitudes and beliefs of straight-identified persons. Tolerant straight Americans conceptualize homosexuality in biological determinist terms while condemning straight Americans 
conceptualize it in terms of choice or learning (Aguero, Bloch, \& Byrne, 1984; Ernulf, Innala, \& Whitam, 1989; Hegarty \& Pratto, 2001; Herek \& Capitanio, 1995; Shmaltz, 1993; Whitley, 1990). The most common explanation of these findings invokes attribution theory (see e.g., Anderson, Krull \& Weiner, 1996, 289-290; Crocker, Major, \& Steele, 1998, 507-508). Building on Goffman's (1963, p. 4) distinction between 'blemishes of individual character' and 'abominations of the body,' attribution theory holds that stigmata understood to be under personal control elicit more hostility, less pity, and less intentions to help than stigmata understood to be beyond personal control (Rodin, Sanchez, Price, \& McElligot, 1989; Weiner, 1995; Wiener, Perry, \& Magnusson, 1988). Constructing biology and choice as polar opposites, attributional theorists argue that teaching biological essentialism might attenuate straight students' heterosexism (Whitley, 1990). Some American journalists have also claimed that straight Americans have become more tolerant of lesbians and gay men because they have become more biological essentialist (e.g., Burr, 1993). American lesbians and gay men also sometimes present this argument as a reason to construct sexual orientation as something biological (Whisman, 1996).

However an immutability-tolerance link could also result from the symbolic meanings accrued by beliefs about sexual orientation. Researchers have long theorized that attitudes not only reflect knowledge about an object, they may also structure expectancies, defend against threats to the ego, and express cherished personal and political values (see e.g., Katz, 1960; Smith, Bruner, \& White, 1956, and Maio \& Olson, 2000 for recent research). Herek $(1986,1987,2000)$ has distinguished between symbolic attitudes which serve to express broad social values and instrumental attitudes which serve to evaluate the actual attitude object. The meanings of the object of symbolic attitudes are constructed; they do not inhere in the object or follow directly from interactions with it (Herek, 2000). Thus, lesbians and gay men may become vehicles for straight people to express their political identities as Christians, conservatives, liberals, or fair-minded people (see Herek, 1987), and people with AIDS may become vehicles for the expression of homophobia (Herek, 2000). Moreover, the symbolic meanings of an attitude object can differ between social groups. According to the symbolic explanation tolerant attitudes and immutability beliefs will only be positively correlated to the degree that immutability beliefs have been constructed as gay-affirmative. Tellingly, some biological essentialists invoke a version of this argument to argue for the politics of biological research;

[T] he only reason why biological explanations have the potential to be a sociopolitical advance for gay people is that the enemies of gay liberation have prematurely, and in my opinion stupidly, committed themselves to the position that homosexuality is an environmentally caused disorder. Now that the environmental part of this position is crumbling, this political group may become embarrassed, and the cause of gay liberation will be, for the moment, advanced. But we can predict that the next generation of rightwing theoreticians will reject these views and simply assert that homosexuality is a genetic pathology (Or if they're really smart, a multifactorial one). (Weinrich, 1995, pp. 201).

Thus, while attribution theory argues that tolerance follows directly from the attributional content of arguments from immutability, the symbolic theory assumes that the relationship between immutability and tolerance is flexible and will depend upon the extent to which particular beliefs are understood as expressions of particular political standpoints.

\section{The Present Research}


Attributional explanations of the immutability-tolerance link have been privileged in social psychological theorizing. In contrast, the present paper argues for a symbolic explanation of this link. Existing findings cannot distinguish the relative strength of the attributional and symbolic explanation for three reasons. First, past studies have shown only correlations between immutability and tolerance but not direct causal effects (see Piskur and Delegman, 1992 for a partial exception). Second, most previous studies employed only American participants (see Ernulf et al., 1989 for an exception). Conrad and Merkins (in press) documented that the American mainstream press have reported findings about the genetics of homosexuality in particularly positive terms. Thus among American heterosexual-identified participants arguments from immutability may be particularly likely to be interpreted as tolerant arguments, and it is particularly difficult to tease apart attributional and symbolic explanations by studying American participants in isolation. Third, arguments from immutability have ambiguous politics, and variations in the constructed meanings of these beliefs within samples have not been assessed in past studies. The present studies address these issues by examining both the attitudes and beliefs of both American and British students, and their judgments about the values that their beliefs expressed. The attributional explanation affords little import to such judgments, the symbolic beliefs explanation assumes that they will moderate the relationship between tolerance and immutability within both samples. These studies also draw on Hegarty and Pratto's (2001) distinction between beliefs in the immutability and fundamentality of sexual orientation. Immutability refers to the fixity of individual sexual orientation over the lifespan and fundamentality to the idea that 'homosexual' and 'heterosexual' are exhaustive and mutually exclusive natural kind categories. The first study focused on American students.

\section{Study 1: American Students’ Beliefs About Sexual Orientation}

\section{Method}

Participants. Fifty-five women, 38 men and 4 straight-identified students in an introductory psychology course at Stanford University in California participated for course credit (age range = $18-21$ years, mean age $=18.9$ years) .

Materials. Two questionnaires were constructed, one for each wave of the study. The first questionnaire consisted of the 10-item short form of the Attitudes Toward Lesbians and Gay Men (ATLG) scale (Herek, 1984, 1993) and a set of six items assessing beliefs about sexual orientation. The ATLG items were followed by a single item allowing participants to identify their sexual orientation as "heterosexual," "gay/lesbian," "bisexual," or "other."

The six belief items were drawn from Hegarty and Pratto's (2001) research on sexual orientation beliefs. The three items with the highest loadings on the fundamentality and immutability belief dimensions were used. The three fundamentality items used were as follows;

Bisexual people are fooling themselves and should make up their minds.

Doctors and psychologists can help people to change their sexual orientations.

Homosexual relationships are fundamentally different from heterosexual relationships.

The three immutability items used were as follows.

If someone comes out as gay or lesbian they were probably attracted to the same sex all along.

Whether a person is gay or straight is pretty much set early on in childhood. 
Sexual orientation is caused by biological factors such as genes and hormones.

These items were presented as 9-point Likert items with high scores indicating agreement with the item. Half of the questionnaires presented the items in the order shown above. The other half reversed this order.

The second questionnaire began with the following instructions;

Read each of the following items carefully and decide who is more likely to agree with each item: 1) a heterosexual person who is tolerant of lesbians and gay men, or (2) a heterosexual person who is condemning of lesbians and gay men. There are no right or wrong answers.

Please also rate how confident you are of each decision. If you are not sure, make the best choice you can.

Each belief item was followed by two items assessing participants' judgment about the values that the belief expressed and confidence in that judgment respectively. These items were as follows;

Who endorses? a) Tolerant b) Condemning.

How confident are you? Very Somewhat Not at all

The belief items were presented in the order in which they appear above.

Procedure. Questionnaires were included in larger questionnaire packets which were distributed in class approximately one month apart. Participants returned these packets one week later and were unsupervised as they completed the questionnaires. Participants' responses were matched across waves using ID number which they wrote on their questionnaires.

\section{Results}

One hundred and eighty-three participants completed Wave 1 and 122 completed Wave 2. The questionnaires of 97 participants could be matched across waves. Matched participants endorsed all belief items to a similar degree as participants who completed only Wave 1 (all $\underline{t}<1)$. Participants who completed only Wave 1 had marginally higher ATLG scores than participants who completed both waves $(\underline{\mathrm{Ms}}=2.55,3.03$ respectively, $\underline{\mathrm{t}}(182)=1.91, \underline{\mathrm{p}}<.06)$.

Wave 1: Attitude-Belief Relationships. ATLG scores were calculated as the average of the ten ATLG items. This attitude measure was internally reliable (Cronbach's alpha $=.89$ ). Factor analysis with varimax rotation of the belief items revealed two factors with eigenvalues of 2.74 and 1.39 respectively which culumatively explained explained $68.9 \%$ of the total variance. No other factors had eigenvalues greater than 1. All immutability items loaded heavily on the first factor (all loadings $>.74$ ) but none of the fundamentality items did (all loadings $<1.31$ ). All three fundamentality items loaded on the second factor (all loadings $>.68$ ) while none of the immutability items did (all loadings $<1.38 \mathrm{l}$ ). The immutability items were negatively correlated with ATLG and the fundamentality items were positively correlated with ATLG (see Table 1). Scores for each set of three items were averaged, giving composite immutability and fundamentality scores. These composites were negatively correlated with each other $(\underline{r}=-.35, \underline{p}<.01)$. These results replicate the findings of Hegarty and Pratto (2001).

Wave 2: Judgments about the Meanings of Beliefs and Confidence Ratings. Participants' judgments about the symbolic meanings of the belief iterms are reported in Table 1. Sign tests showed that most participants judged each fundamentality item as expressive of condemnation (all $\mathrm{p}<.01$ ) and eacy immutability item as expressive of tolerance (Item $1, \mathrm{p}<.05$, Items 2 and $3 ; \mathrm{p}<$ 
$.01)$. Responses to the confidence items were converted into three point scales. Participants who judged the first fundamentality item (about bisexuality) to express condemnation were significantly more confident in their judgment than participants who judged it to express tolerance $(\mathrm{t}(94)=3.38$, $\mathrm{p}<.01$ ). Participants who judged the third immutability item (about biology) to express tolerance were more confident than participants who judged it to express condemnation $(\mathrm{t}(96)=2.22$, $\mathrm{p}$ $<.05)$. Otherwise, participants who rated each belief as expressive of tolerance and expressive of condemnation did not differ in their mean confidence ratings (all $\underline{\mathrm{t}}<1.6$, all $\underline{\mathrm{p}}<.12$, see Table 1 ).

Integrating Waves 1 \& 2: Testing the Symbolic Beliefs Explanation. Finally, the relevance of participants' judgments about their beliefs for the relationships between their beliefs and attitudes was assessed. This analysis involved splitting the sample into two groups according to their judgments about their beliefs expressed at Wave 2 and comparing the strength of the relevant attitude-belief correlation across the two groups. Recall that the symbolic beliefs explanation predicts that the attitude-belief correlation will vary according to the constructed meaning of those beliefs, while the attributional explanation predicts that this correlation will be similar across the two groups.

This analysis was first performed for the fundamentality beliefs. The sample was split into a condemnation-expressive group (which included all participants who judged the three fundamentality items as expressive of condemnation, $\mathrm{N}=82$ ) and an ambivalence-expressive group (which included the participants who judged one or more of those items as expressive of tolerance, $\mathrm{N}=12$ ). ${ }^{1}$ Condemnation-expressives and ambivalence-expressives did not differ in their ATLG scores $(\underline{\mathrm{Ms}}=3.06,3.34$ respectively, $\underline{\mathrm{t}}<1)$, immutability beliefs $(\underline{\mathrm{M} s}=5.66,5.19$ respectively, $\underline{\mathrm{t}}<$ $1)$, or fundamentality beliefs $(\underline{\mathrm{Ms}}=3.25,3.77$ respectively, $\underline{\mathrm{t}}<1)$. ATLG and fundamentality beliefs were strongly positively correlated among the condemnation-expressives and ambivalenceexpressives $(\underline{\mathrm{r}}=+.74, \underline{\mathrm{p}}<.001, \underline{\mathrm{r}}=+.73, \underline{\mathrm{p}}<.05$ respectively). These correlations are statistically equivalent (Fisher's $\underline{Z}<1$ ).

A similar analysis was performed for the immutability beliefs. Participants in the tolerance-expressive group judged all three immutability items as expressing tolerance $(\mathrm{N}=57)$ while those in the ambivalence-expressive group judged one or more of those items as expressing condemnation $(\mathrm{N}=40)$. Tolerance-expressives and ambivalence-expressives had similar ATLG scores (both $\underline{\mathrm{M}} \mathrm{s}=3.04, \underline{\mathrm{t}}<1)$, immutability beliefs $(\underline{\mathrm{M}} \mathrm{s}=5.73,5.47$ respectively, $\underline{\mathrm{t}}<1)$, and fundamentality beliefs $(\underline{\mathrm{Ms}}=3.17,3.38$ respectively, $\underline{\mathrm{t}}<1)$. Among the tolerant-expressives, ATLG and immutability beliefs were significantly negatively correlated $(\underline{r}=-.60, \underline{p}<.001)$, but this relationship was not significant among the ambivalent expressives $(\underline{r}=-.15, \underline{p}>.15)$.

Furthermore, the difference between these two correlations was significant (Fisher's $\underline{Z}=2.07, \underline{p}<$ .05 two-tailed). In other words the tolerance-immutability link in this sample was contingent upon participants' judgment that all of the immutability beliefs would by most likely expressed by tolerant heterosexual persons.

\section{Discussion}

As in Hegarty and Pratto's (2001) study tolerant participants endorsed immutability beliefs and condemning participants endorsed fundamentality beliefs about sexual orientation. However, the immutability-tolerance link was contingent upon participants' judgments that all three immutability beliefs expressed tolerance. The relationship between fundamentality beliefs and attitudes was not qualified by participants' judgments in this way. 
These results support the symbolic beliefs explanation but not the attributional explanation of the tolerance-immutability link. Attribution theory says little about the importance of the constructed meanings of immutability beliefs. However, judgments about who would be most likely to express these beliefs moderated the very attitude-belief relationship which attribution theory holds to be fundamental. To extend this research, a second study was conducted in Britain where arguments from immutability had been popularly represented in a more negative light (Conrad \& Merkins, in press).

\section{Study 2: British Students Beliefs About Sexual Orientation.}

\section{Method}

Participants. Sixty four female students and eight male students in one of two introductory psychology courses at the University of Surrey in the South of England participated in return for course credit (age range $=18-41$ years, mean age $=20.6$ years).

Materials. Two questionnaires were constructed as before. The materials used in this study were identical to those used in Study 1 with two revisions. The ATLG scale and the belief items were presented in 7-point Likert format and all of the belief items were presented in the order in which they are presented in Table 1.

Procedure. As in Study 1, Wave 2 was completed approximately one month after Wave 1. The questionnaires were completed during class time. Participants were advised to write an identifying number on each questionnaire to afford matching of the questionnaires across both waves of the study. During the first wave of administration, one participant pointed out that one of the items on the ATLG scale "State laws prohibiting private, consenting lesbian behavior should be loosened" did not apply to the British context. As a result participants in one session of Wave 1 were instructed that they could skip this particular item if they perceived it to be irrelevant to their cultural context.

Results

One hundred and twelve participants completed Wave 1 and 83 completed Wave 2. Questionnaires for 76 participants could be matched using ID numbers. Two participants who identified as Americans, one who identified as lesbian, and one who identified as bisexual were excluded. The analysis presented below is based on the remaining 72 participants. Participants who completed both waves of the study and participants who completed only the first wave had similar ATLG scores $(\underline{\mathrm{t}}<1.3, \underline{\mathrm{p}}>.20)$, and similar responses to all six belief items (all $\underline{\mathrm{t}}<1.1$, all $\underline{\mathrm{p}}$ $>$.29).

Wave 1: Attitude-Belief Relationships. The ATLG was highly reliable in this sample $($ Cronbach's alpha $=.87)$. Factor analysis with varimax rotation revealed a two-factor structure to participants' beliefs. However, this structure differed somewhat from that observed in Study 1. The first factor had an Eigenvalue of 2.27 and explained $37.9 \%$ of the variance in the data. All immutability items all loaded heavily on this factor (all loadings $>.72$ ), but the first fundamentality item also loaded on this factor (loading $=.58$ ). The remaining two items did not (both loadings 
$<.10)$. The second factor had an Eigenvalue of 1.34 and explained an additional $22.3 \%$ of the variance in the data. The second and third fundamentality items loaded on the second (both loadings $>.73$ ), but the first fundamentality item did not (loading $=1.271)$. None of the three immutability items loaded on this factor (all loadings $<$ I.37l). ${ }^{3}$

The composite fundamentality measure was constructed as the average of the second and third fundamentality items which were significantly correlated $(\underline{r}=.25, \underline{p}<.05)$. The first fundamentality item was uncorrelated with the other two items (both $\underline{r}<\mid$.14l). The composite measure of immutability was constructed as the average of the three immutability items as before. As in Study 1 all three fundamentality items were positively correlated with ATLG (see Table 2). However, in contrast to Study 1, none of the immutability beliefs were significantly correlated with ATLG (see Table 2), and the immutability and fundamentality scores were uncorrelated $(\underline{r}=-.10, \underline{p}$ $>$.38). Thus, in this sample, the tolerance-immutability link predicted by attribution theory was not observed.

Wave 2: Judgments about the Meanings of Beliefs and Confidence Ratings. Sign tests revealed that most participants judged each fundamentality belief as expressive of condemnation (all $\mathrm{p}<.01$ ) and each immutability belief as expressive of tolerance (Item $1, \mathrm{p}<.05$, Items 2 and 3 , $\mathrm{p}<.01)$. Participant's expressed confidence in their judgments was examined as before.

Participants who judged the first fundamentality item to be expressive of condemnation were more confident than participants who judged the item to be expressive of tolerance $(\mathrm{t}(71)=4.11, \underline{\mathrm{p}}<$ .001). Participants who judged the second and third immutability item as expressive of tolerance were more confident than participants who judged them to be expressive of condemnation (Item 2; $\underline{\mathrm{t}}(71)=2.32, \underline{\mathrm{p}}<.05$, Item $3 ; \underline{\mathrm{t}}(71)=2.11, \underline{\mathrm{p}}<.05)$. Otherwise, differences in confidence ratings were not significant (all $\underline{\mathrm{t}}<1.65$, all $\mathrm{p}>.10$, see Table 2 ).

Wave 1 \& 2: Testing the Symbolic Beliefs Explanation. As in Study 1, the participants were subdivided into two groups based on their judgments about the symbolic meanings of the beliefs. Fifty-six participants judged both fundamentality items 2 and 3 as expressive of condemnation and 16 participants judged one or both as expressive of tolerance. These two groups were labeled the condemnation-expressives and ambivalence-expressives as before. Ambivalent-expressives had higher ATLG scores than condemning-expressives $(\underline{\mathrm{Ms}}=2.46,1.93$ respectively, $\underline{\mathrm{t}}(70)=2.11, \underline{\mathrm{p}}<$ $.05)$ and also had higher fundamentality scores $(\underline{\mathrm{M} s}=3.84,2.75$ respectively, $\underline{\mathrm{t}}(70)=3.08, \underline{\mathrm{p}}<$ $.01)$. Immutability scores were equivalent across the two groups $(\mathrm{t}<1.6, \mathrm{p}>.12)$. Next, the relationship between fundamentality beliefs and attitudes was assessed separately for these two groups. ATLG scores and fundamentality beliefs were significantly positively correlated among the condemning-expressives $(\underline{\mathrm{r}}=.41, \mathrm{p}<.01)$, but not among the ambivalent-expressives $(\underline{\mathrm{r}}=.22$, $\mathrm{p}>.50$ ). However, as these correlations do not differ significantly from each other (Fisher's $\underline{Z}<1$ ) judgments about fundamentality beliefs cannot be said to moderate the relationship between those beliefs and ATLG. As only 6 participants judged the first fundamentality item as expressive of tolerance, this item was not analyzed further.

A similar analysis was performed on the immutability beliefs. The forty-one tolerantexpressive participants judged that all three immutability items expressed tolerance, while the 31 ambivalent-expressive participants judged that one or more expressed condemnation. ATLG scores and fundamentality scores were similar in each group (both $\underline{\mathrm{t}}<1$ ). However, tolerant-expressives had higher immutability scores than ambivalent expressives $(\underline{\mathrm{M} s}=4.86,3.85$ respectively, $\underline{\mathrm{t}}(70)=$ $3.95, \mathrm{p}<.001)$. The relationship between attitudes and beliefs at Wave 1 was examined separately for each group as before. ATLG and immutability were significantly negatively 
correlated among tolerant-expressives $(\underline{r}=-.37, \underline{p}<.05)$. However, among ambivalent-expressives a nonsignificant positive correlation between ATLG and immutability was observed $(\underline{r}=+.20, \underline{p}>$ .28). These two correlations were significantly different from each other (Fisher's $\underline{Z}=2.38, \underline{p}<$ .05 , two-tailed). Here, as before, participants' judgments about immutability beliefs significantly moderated the relationship between immutability beliefs and ATLG.

\section{Discussion}

In this second study, condemning participants endorsed fundamentality beliefs, but attitudes toward lesbians and gay men and immutability beliefs were uncorrelated in the sample as a whole. This latter result constitutes further evidence against the attributional explanation of the toleranceimmutability link. As in Study 1, an immutability-tolerance link was only observed among participants who had judged all of the immutability beliefs as most likely to be expressed by tolerant straight persons.

\section{General Discussion}

Among American and British students groups fundamentality beliefs were associated with condemnation, while the link between immutability and tolerance was contingent upon the construction of the immutability beliefs as gay-affirmative. However, only in the American sample were immutability beliefs and tolerant attitudes significantly correlated, and only in the British sample were participants' judgments about the sexual orientation beliefs related to their personal attitudes and beliefs.

The lack of an overall tolerance-immutability link in the British sample might suggest that the tolerance-immutability link is a 'culture-bound' phenomenon. However, conclusions about broad cultural differences may be premature. While arguments from immutability about sexual orientation were reported in more positive terms in the United States than in Britain (Conrad \& Merkens, in press), an equivalent proportion of the participants in both samples were categorized as ambivalent-expressives in regard to immutability beliefs ( $40.4 \%$ and $41.9 \%$ respectively). Furthermore, the correlations between immutability and tolerance were equivalent among the American and British tolerant-expressives ( $\underline{\mathrm{r}}=-.60,-.37$ respectively) or ambivalent-expressives ( $\underline{\mathrm{r}}$ $=-.15,+.20$ respectively). Future studies using larger and more representative samples are required to clarify if there are consistent cross-cultural differences in the validity of attributional analysis of stigma (see e.g., Crandall, D'Anello, Sakall, Lazarus, Wieczorkowska \& Feather, 2001).

These results challenge the reliance on attribution theory as the sole framework for explaining the immutability-tolerance link in regard to sexual orientation. Attribution theory has often been critiqued for adopting an essentialist approach that overlooks the context-bound meanings and constructive effects of linguistic signifiers (e.g., Edwards \& Potter, 1993; Hilton, 1990: Kessler \& McKenna, 1978). Similarly, attribution theory appears to have assumed (in an essentialist manner) that immutability arguments have only one interpretation of social psychological importance. In so doing, attribution theory has lent political support to biological essentialist theories of sexual orientation which, as noted in the introduction, have very real limits as gay-affirmative strategies. Given the variety of symbolic uses that such hypothetical biological differences can come to serve, presenting biological determinism as a pro-gay strategy in the classroom or in an advertisement may well strengthen symbolic associations between tolerance and biological determinism more than it actually produces genuine attitude change. Moreover, yoking 
tolerance to biological determinism undermines pedagogical practices aimed at developing students' skills at detecting and critiquing masculinist and heterosexist ideological assumptions in the biological science (e.g., Gilbert, 2000).

The present studies are consistent with the proposition that heterosexual-identified people may be constructing their beliefs about brain nuclei, genes, and hormones to fit their sexual politics rather than the reverse. As in other domains, people may shift their opinions to be consistent with the perceived views of groups with which they identify and to be distinct from those of groups with which they disidentify (e.g., Wood, Pool, Leck, \& Purvis, 1996). Thus, immutability beliefs may be associated with tolerant heterosexual people leading individuals who are tolerant and condemning to take up positions in favor of either 'biology' of 'choice' respectively. However, the tolerant/condemning and immutability/mutability axes are not completely overlapping and the present study shows that to the extent that they are perceived as distinct, the correlation between immutability beliefs and tolerant attitudes is weakened.

I hope the present research provokes discussion within lesbian and gay psychology of how intellectual ideas traffic across the Atlantic. Lesbian and gay psychology in the United States remains invested in liberal humanist morality and positivist-empiricist methods even a generation after Kitzinger's (1987) important analysis of the sub-field (see also Clark, 2000). In contrast, European lesbian and gay psychology is developing through more explicit conversations with critical psychological frameworks. This latter pattern is welcome, although political and empirical reasons to employ quantitative methods may remain (see Hegarty, 2001; Kitzinger, 1997). The present research is hoped to contribute to discussions of methodological politics by demonstrating the degree to which quantitative research practices can be used to engage with critiques of essentialism.

Kitzinger's (1987) critique of the liberal humanism of lesbian and gay psychology remains relevant for lesbian and gay psychology in the current neo-liberal order. Public discourse about sexual minorities may be more explicitly tolerant than a generation ago, but Kitzinger's work reminds us that 'tolerance' is itself a rather abstract value which does not necessarily work in the interests of lesbians and gay men. More than ever lesbian and gay psychologists need to critically examine the heterosexist implications of arguments that position themselves as liberal, humanistic, or tolerant. Biological determinist arguments are often constructed as such, yet they continue to position homosexuality as an 'abomination of the body' (c.f., Goffman, 1963). Attribution theory similarly suggests that stigmatized groups can -- at best -- hope for pity and tolerance for their unchosen and inevitably devalued differences. Lesbian and gay psychologists ought to take such accounts as object of critical analysis rather than privilege them as frameworks for theorizing.

\section{Footnotes.}

1. The term 'queer' has come to have several meanings. I refer here to 'queer' as a mode of understanding and enacting sexuality which refuses categorical imperatives and which reworks the violen implications of the perjerative term 'queer' itself rather than as an umbrella term for persons who identify as gay, lesbian, bisexual, transgendered and/or intersexed.

2. Only participants who rendered a judgment for all three beliefs of a given sort were categorized in this procedure. As a result the total number of participants in these two groups is less than 97.

3. This factor analysis was repeated using an oblique rotation. Loadings and factors structure were essentially unchanged. 


\section{References}

Aguero, J.E., Bloch, L., \& Byrne, D. (1984). The relationship among sexual beliefs, attitudes, experience, and homophobia. Journal of Homosexuality, 10, 95-107.

Anderson, C. A., Krull, D.S., \& Weiner, B. (1996). Explanations: Processes and consequences. In E.T. Higgins \& A. W. Kruglanski (Eds.) Social Psychology: Handbook of Basic Principles (pp. 271-296). Guilford: New York.

Bailey, J. M., \& Zucker, K. J. (1995). Childhood sex-typed behavior and sexual orientation: A conceptual analysis and quantitative review. Developmental Psychology, 31, 43-55.

Bell, A. P., Weinberg, M. S., \& Hammersmith, S. K. (1981). Sexual preference: Its development in men and women. Bloomington: Indiana University Press.

Bogaert, A.F., \& Herschberger, S. (1999). The relation between sexual orientation and penile size. Archives of Sexual Behavior, 28, 213-221.

Burr, C. (1993). Homosexuality and biology. The Atlantic Monthly, 271, 47-65.

Butler, J. (1990). Gender trouble: Feminism and the subversion of identity. Routledge: New York.

Byne, W. \& Parsons, B. (1993). Human sexual orientation: The biologic theories reappraised. Archives of General Psychiatry, 50, 228-239.

Clark, V. (2000). 'Stereotype, attack, and stigmatize those who disagree;' Employing scientific rhetoric in debates about lesbian and gay parenting. Feminism \& Psychology, 10, 152129.

Conrad, P., \& Markens, S. (in press). Constructing the 'gay gene' in the news: Optimism and skepticism in the American and British press. Health

Crandall, C.S., Danello, S., Sakall, N., Lazarus, E., Wieczorkowska, G., \& Feather, N.T. (2001). An attribution-value model of prejudice: Anti-fat attitudes in six nations. Personality and Social Psychology Bulletin, 27, 30-37.

Crocker, J., Major, B., \& Steele, C. (1998). Social stigma. In D.T. Gilbert, S.T. Fiske, \& G. Lindzey (Eds.) The Handbook of Social Psychology: Volume 2 (pp. 504-553). New York: Oxford University Press.

Duggan, L. (1995). Making it perfectly queer. In L. Duggan \& N. Hunter, Sex wars: Sexual dissent and political culture. New York: Routledge.

Edwards, D., \& Potter, J. (1993). Language and causation: A discursive action model of description and attribution. Psychological Review, 100, 23-41.

Ernulf, K.E., Innala, S.M., \& Whitman, F.L. (1989). Biological explanation, psychological explanation, and tolerance of homosexuals: A cross-national analysis of beliefs and attitudes. Psychological Reports, 65, 1003-1010.

Fausto-Sterling, A. (2000). Sexing the body: Gender politics and the construction of sexuality. Basic Books.

Garber, M. (1995). Vice versa: Bisexuality and the eroticism of everyday life. Simon \& Schuster: New York. 28-30.

Gideonse, T. (May 27th, 1997). Are we an endangered species? The Advocate, Issue 734,

Gilbert, S.F. (2000). Mainstreaming feminist critiques into the biology curriculum. In R. Reid \& S. Traweek (Eds.), Doing Science + Culture (pp. 199-220). Routledge: New York. 
Golden, C. (1994). Our politics, our choices: The feminist movement and sexual orientation. In B. Greene \& G.M. Herek (Eds.) Lesbian and gay psychology: Theory, research and clinical applications (pp. 54-70). Thousand Oaks, CA: Sage.

Halley, J.E. (1994). Sexual orientation and the politics of biology: A critique of the argument from immutability. Stanford Law Journal, 36, 301-366.

Hamer, D.H., Hu, S., Magnuson, V.L., Hu, N., \& Pattatucci, A.M.L. (1993). A linkage between DNA markers on the X chromosome and male sexual orientation. Science, 261, 321-327.

Hegarty, P. (2001). "Real science," phantom heterosexuality, and the gender of my lab coat: Toward a new laboratory manual for lesbian and gay psychology. International Journal for Critical Psychology.

Hegarty, P. \& Pratto, F. (2001). The effects of category norms and stereotypes on explanations of intergroup differences. Journal of Personality and Social Psychology, 80, 723-735.

Hegarty, P., \& Pratto, F. (2001). Sexual orientation beliefs: Their relationship to anti-gay attitudes and biological determinist arguments. Journal of Homosexuality, 41 121-135.

Herek, G.M. (1984). Attitudes towards lesbians and gay men: A factor analytic study. Journal of Homosexuality, 10, 1-21.

Herek, G.M. (1986). The instrumentality of attitudes: Toward a neofunctional theory. Journal of Social Issues, 42, 99-114.

Herek, G.M. (1987). Can functions be measured? A new perspective on the functional approach to attitudes. Social Psychology Quarterly, 50, 285-303.

Herek, G.M. (1994). Assessing heterosexuals' attitudes toward lesbians and gay men: A review of empirical research with the ATLG scale. In G.M. Herek \& B. Greene (Eds.) Lesbian and gay psychology: Theory, research and clinical applications, (pp. 206-228). Thousand Oaks, CA: Sage.

Herek, G.M. (2000). The social construction of attitudes: Functional consensus and divergence in the U.S. public's reaction to AIDS. In G.R. Maio \& J.M. Olson (Eds.) Why we evaluate: Functions of attitudes (pp. 325-364). Mahway, NJ: Lawrence Erlbaum.

Herek, G.M., \& Capitanio, J.P. (1995). Black heterosexuals' attitudes toward lesbians and gay men in the United States. The Journal of Sex Research, 32, 95-105.

Hilton, D. J. (1990). Conversational processes and causal attribution. Psychological Bulletin, 107, 65-81.

Katz, D. (1960). The functional approach to the study of attitudes. Public Opinion Quarterly, 24, 163-204.

Kessler, S. \& McKenna, W. (1978). Gender: An ethnomethodological approach. New York: Wiley.

Kitzinger, C. (1987). The social construction of lesbianism. London: Sage.

Kitzinger, C. (1997). Lesbian and gay psychology: A critical analysis. In I. Fox (Ed), Critical psychology: An introduction (pp. 202-216). London: Sage.

LeVay, S. (1991). A difference in hypothalamic structure between heterosexual and homosexual men. Science, 253, 1034-1037.

LeVay, S. (1996). Queer science: The use and abuse of research into homosexuality. Cambridge, MA: MIT Press.

Maio,G., \& Olson, J. (1999). Why we evaluate: Functions of attitudes. Hillsdale, NJ: Lawrence Erlbaum Associates. 
McFadden, D., \& Pasanen, E.G. (1998). Comparison of the auditory systems of heterosexuals and homosexuals: Click-evoked otoacoustic emissions. Procedings of the National Academy of Sciences, 95, 2709-2713.

Peplau, L.A., Garnets, L.D., Spalding, L.R., Conley T.D., \& Veniegas, R.C. (1998). A critique of Bem's "Exotic Becomes Erotic" theory of sexual orientation. Psychological Review, $\underline{105}, 387-394$.

Phelan, S. (2001). Sexual strangers: Gays, lesbians, and dilemmas of citizenship. Philadelphia, PA: Temple University Press.

Piskur, J., \& Delegman, D. (1992). Effect of reading a summary of research about biological bases of homosexual orientation on attitudes toward homosexuals. Psychological Reports, 71, 1219-1225.

Rodin, M., Price, J., Sanchez, F., \& McElligot, S. (1989). Derogation, exclusion and unfair treatment of persons with social flaws: Controllability of stigma and the attribution of prejudice. Personality and Social Psychology Bulletin, 15, 439-451.

Schmalz, J. (March 15, 1993). Poll finds an even split on homosexuality's cause. New York Times, A14.

Sedgwick, E.K. (1993). How to bring your kids up gay. In M. Warner (Ed), Fear of a queer planet: Queer politics and social theory (pp. 69-81). Minneapolis, MN: University of Minnesota Press.

Smith, M.B., Bruner, J.S., \& White, R.W. (1956). Opinions and personality. New York: Wiley.

Stein, E. (1999). The mismeasure of desire: The science, theory, and ethics of sexual orientation. New York: Oxford.

Terry, J. (1997). The seductive power of science in the making of deviant subjectivity. In V. A. Rosario (Ed.), Science and homosexualities (pp. 271-298). New York: Routledge.

Terry, J. (1999). An American obsession: Science, medicine, and the place of homosexuality in modern society. Chicago: University of Chicago Press.

Weiner, B. (1995). Judgments of responsibility: Foundations for a theory of social conduct. New York: Guildford Press.

Weiner, B., Perry, R.P., \& Magnusson, J. (1988). An attributional analysis of reactions to stigma. Journal of Personality and Social Psychology, 55, 738-748.

Weinrich, J.D. (1995). Biological research on sexual orientation: A critique of the critics. Journal of Homosexuality, 28, 197-213.

Whisman, V. (1996). Queer by choice: Lesbians, gay men and the politics of identity. New York: Routledge.

Whitley, B.E., Jr. (1990). The relationship of heterosexuals' attributions for the causes of homosexuality to attitudes towards lesbians and gay men. Personality and Social Psychology Bulletin, 16, 369-377.

Williams, T.J., Pepitone, M.E., Christensen, S.E., Cooke, B.M., Huberman, A.D., Breedlove, N.J., Breedlove, T.J., Jordan, C.L. \& Breedlove, S.M. (2000). Finger-length ratios and sexual orientation. Nature, 404, 455-456.

Wood, W., Pool, G.P., Leck, K., \& Purvis, D. (1996). Self-definition, defensive processing and influence: The normative impact of minority and majority groups. Journal of Personality and Social Psychology, 71, 1181-1193.

(Unknown). psychology/ucdavis.edu/rainbow/htmp/sacramento_study.html. Downloaded, May 15th, 2001. 
Table 1. Mean Belief Scores (standard deviations in parentheses), Correlations with ATLG, and Confidence Ratings for Judgments about Beliefs (Study 1).

\begin{tabular}{|c|c|c|c|c|}
\hline & \multicolumn{2}{|c|}{ Wave 1: Beliefs } & \multicolumn{2}{|c|}{ Wave 2: Confidence } \\
\hline & Mean (S.D.) & r.ATLG & Tolerant & Condemning \\
\hline \multicolumn{5}{|l|}{ Fundamentality } \\
\hline $\begin{array}{l}\text { Bisexuals should make } \\
\text { up their minds }\end{array}$ & $\begin{array}{l}3.04 \\
(2.08)\end{array}$ & $+.50 * * *$ & $\begin{array}{l}1.83 \\
(\mathrm{n}=6)\end{array}$ & $\begin{array}{l}2.45 \\
(\mathrm{n}=89)\end{array}$ \\
\hline $\begin{array}{l}\text { Doctors can help people } \\
\text { to change }\end{array}$ & $\begin{array}{l}2.47 \\
(2.08)\end{array}$ & $+.59 * * *$ & $\begin{array}{l}2.46 \\
(\mathrm{n}=3)\end{array}$ & $\begin{array}{l}1.67 \\
(\mathrm{n}=93)\end{array}$ \\
\hline $\begin{array}{l}\text { Homosexual relationships } \\
\text { are different } \\
\text { Immutability }\end{array}$ & $\begin{array}{l}4.39 \\
(2.56)\end{array}$ & $+.63 * * *$ & $\begin{array}{l}2.45 \\
(\mathrm{n}=5)\end{array}$ & $\begin{array}{l}2.40 \\
(\mathrm{n}=92)\end{array}$ \\
\hline $\begin{array}{l}\text { If someone comes out, they } \\
\text { were attracted all along }\end{array}$ & $\begin{array}{l}5.34 \\
(2.42)\end{array}$ & $-.22 *$ & $\begin{array}{l}2.26 \\
(n=62)\end{array}$ & $\begin{array}{l}2.05 \\
(\mathrm{n}=36)\end{array}$ \\
\hline $\begin{array}{l}\text { Being gay or straight is set } \\
\text { early on in childhood }\end{array}$ & $\begin{array}{l}5.56 \\
(2.37)\end{array}$ & $-.40 * * *$ & $\begin{array}{l}2.21 \\
(\mathrm{n}=83)\end{array}$ & $\begin{array}{l}2.36 \\
(n=14)\end{array}$ \\
\hline $\begin{array}{l}\text { Sexual orientation is caused } \\
\text { by biological factors }\end{array}$ & $\begin{array}{l}5.81 \\
(2.34)\end{array}$ & $-.55 * * *$ & $\begin{array}{l}2.56 \\
(\mathrm{n}=91)\end{array}$ & $\begin{array}{l}2.17 \\
(\mathrm{n}=6)\end{array}$ \\
\hline
\end{tabular}

Note: r.ATLG $=$ Correlation with ATLG, Condemning $=$ Number of Participants Judging the Item as Expressing Condemnation Tolerant $=$ Number of Participants Judging the Item as Expressing

Tolerance,. $* \mathrm{p}<.05 * * * \mathrm{p}<.001$ 
Table 2. Mean Belief Scores (standard deviations in parentheses), Correlations with ATLG, and Confidence Ratings for Judgments about Beliefs (Study 2).

\begin{tabular}{|c|c|c|c|c|}
\hline & \multicolumn{2}{|c|}{ Wave 1: Beliefs } & \multicolumn{2}{|c|}{ Wave 2: Confidence Ratings } \\
\hline & Mean (S.D.) & r.ATLG & Tolerant & Condemning \\
\hline \multicolumn{5}{|l|}{ Fundamentality } \\
\hline $\begin{array}{l}\text { Bisexuals should make } \\
\text { up their minds }\end{array}$ & $\begin{array}{l}2.82 \\
(1.67)\end{array}$ & $+.41 * *$ & $\begin{array}{l}1.25 \\
(n=4)\end{array}$ & $\begin{array}{l}2.42 \\
(\mathrm{n}=68)\end{array}$ \\
\hline $\begin{array}{l}\text { Doctors can help people } \\
\text { to change }\end{array}$ & $\begin{array}{l}2.32 \\
(1.61)\end{array}$ & $+.26^{*}$ & $\begin{array}{l}2.00 \\
(\mathrm{n}=5)\end{array}$ & $\begin{array}{l}2.38 \\
(\mathrm{n}=67)\end{array}$ \\
\hline $\begin{array}{l}\text { Homosexual relationships } \\
\text { Are different } \\
\text { Immutability }\end{array}$ & $\begin{array}{l}3.67 \\
(1.77)\end{array}$ & $+.35^{* *}$ & $\begin{array}{l}2.00 \\
(\mathrm{n}=13)\end{array}$ & $\begin{array}{l}2.24 \\
(\mathrm{n}=59)\end{array}$ \\
\hline $\begin{array}{l}\text { If someone comes out, they } \\
\text { were attracted all along }\end{array}$ & $\begin{array}{l}4.08 \\
(1.59)\end{array}$ & -.17 & $\begin{array}{l}2.00 \\
(n=46)\end{array}$ & $\begin{array}{l}2.23 \\
(\mathrm{n}=26)\end{array}$ \\
\hline $\begin{array}{l}\text { Being gay or straight is set } \\
\text { early on in childhood }\end{array}$ & $\begin{array}{l}4.69 \\
(1.40)\end{array}$ & -.12 & $\begin{array}{l}2.13 \\
(\mathrm{n}=54)\end{array}$ & $\begin{array}{l}1.75 \\
(\mathrm{n}=18)\end{array}$ \\
\hline $\begin{array}{c}\text { Sexual orientation is caused } \\
\text { by biological factors }\end{array}$ & $\begin{array}{l}4.50 \\
(1.29)\end{array}$ & -.14 & $\begin{array}{l}2.93 \\
(\mathrm{n}=61)\end{array}$ & $\begin{array}{l}2.00 \\
(\mathrm{n}=11)\end{array}$ \\
\hline
\end{tabular}

Note: r.ATLG $=$ Correlation with ATLG, Tolerant $=$ Number of Participants Judging the Item as Expressing Tolerance, Condemning $=$ Number of Participants Judging the Item as Expressing Condemnation. $* \mathrm{p}<.05 * * \mathrm{p}<.01$. 